\title{
台湾における製紙用パルプ原料の需給についで*
}

\section{Supply and Demand of Papermaking Fiber Raw Materials in Taiwan}

\author{
Ching-Biau Chang \\ Cheng Loong Co. Ltd., Taiwan, ROC
}

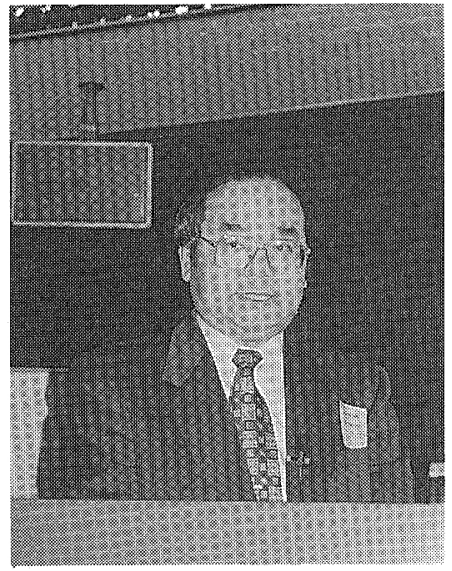

The paper industry of Taiwan is also affected by the slow pace of rebound after the previous big dip globally, the development has slowed substantially. However, in pace with the overall economic expansion of Taiwan, the paper industry is still maintaining steady growth. The total production of paper and board in 1996 reached 4.34 million metric tonnes, growing $2.2 \%$ as compared with the previous year. The ratio of board to paper products is $74: 26$, suggesting an export oriented economic and trade structure of Taiwan. On import and export of paper products, the dependency reached $24 \%$ and $27 \%$, or 1.08 and 0.92 million metric tonnes, re-spectively. Among the imports, newsprint accounted for 350,000 metric tonnes; whereas among the exports, 400,000 metric tonnes of industrial paper and 370,000 metric tonnes of coated paperboard made up the majority. This suggests that although the overall productions and sales are roughly in balance, there is imbalance of the paper varieties and grades needing adjustment by import and export. The annual apparent paper and board consumption of 1996 reached 456 million metric tonnes, although slightly lower than the peak 473 million metric tonnes reached in 1994, the average per capita consumption still reached $212 \mathrm{~kg}$, and ranked among the top ten paper consumer nations of the world.

(quoted from the original paper)

\section{1. 紙・板紙の生産量と売上げ高}

(注：トンニメートルトン) 台湾の製紙産業も, 先の世界的不況の後, 回復速度 が楥慢であることに影響され，実質的にはゆっくりと した発展である。しかし, 台湾の全経済の拡大ペース に合わせて，製紙産業は，尚も着実な成長を維持して いる。1996 年の紙・板紙の全生産量は 434 万トンに

*(翻訳) 王子製紙株式会社新技術研究所 辻本 直彦
達し，前年比 $2.2 \%$ 增である（図 1，2）。生産量で 比較して，板紙/紙は，74/26で，これは，台湾の輸 出志向型経済・貿易構造を示している。紙生産品の輸 入/輸出のそれぞれの依存度は，24\%/27\%で，量にし て, 108 万トン/92 万トンである(表 1)。輸入紙の中で, 主要なものは, 新聞用紙の 35 万トン, 一方輸出紙の 中では, 産業用紙の 40 万トンおよび塗工板紙の 37 万 トンである。このことは，おおまかに言って，全生産 量と売上高はバランスしているが, 輸出入で調整が必 要なアンバランスな点は，紙の種類とグレードである。 


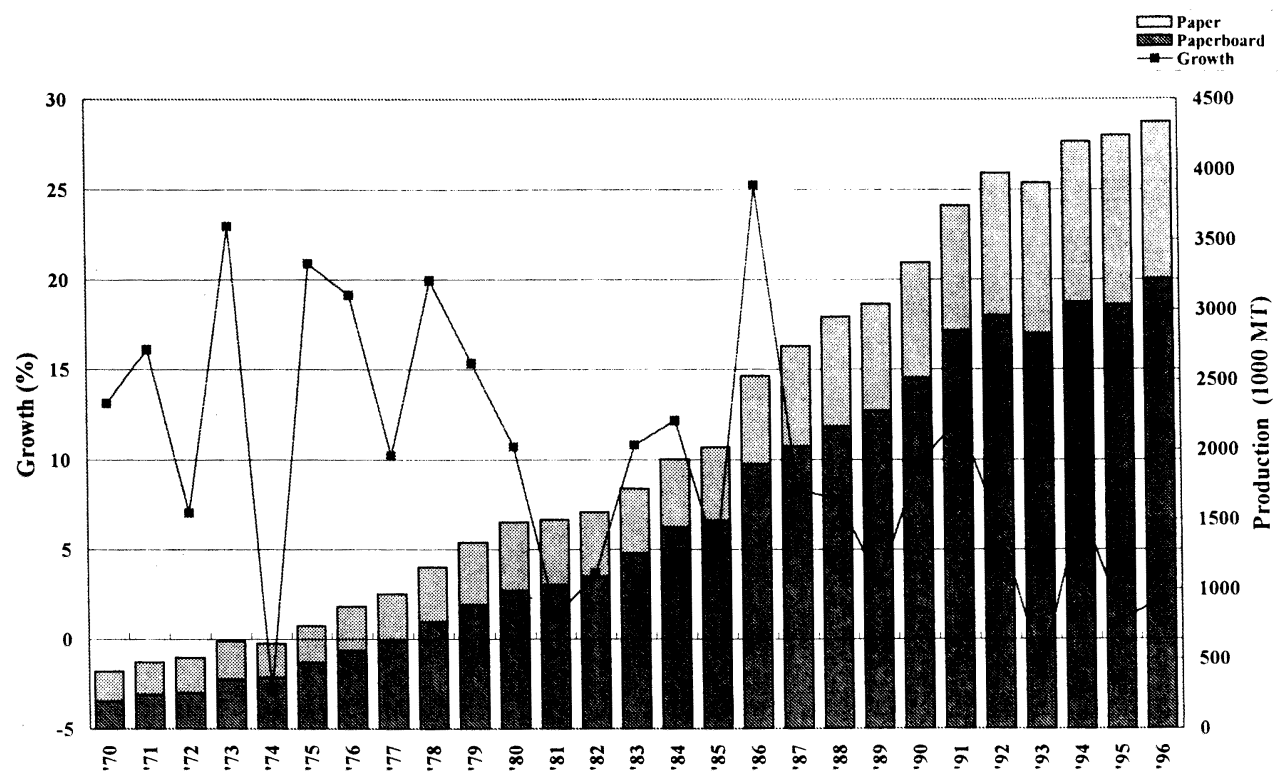

Fig.1 Production of Paper and Paperboard in Taiwan over The Years

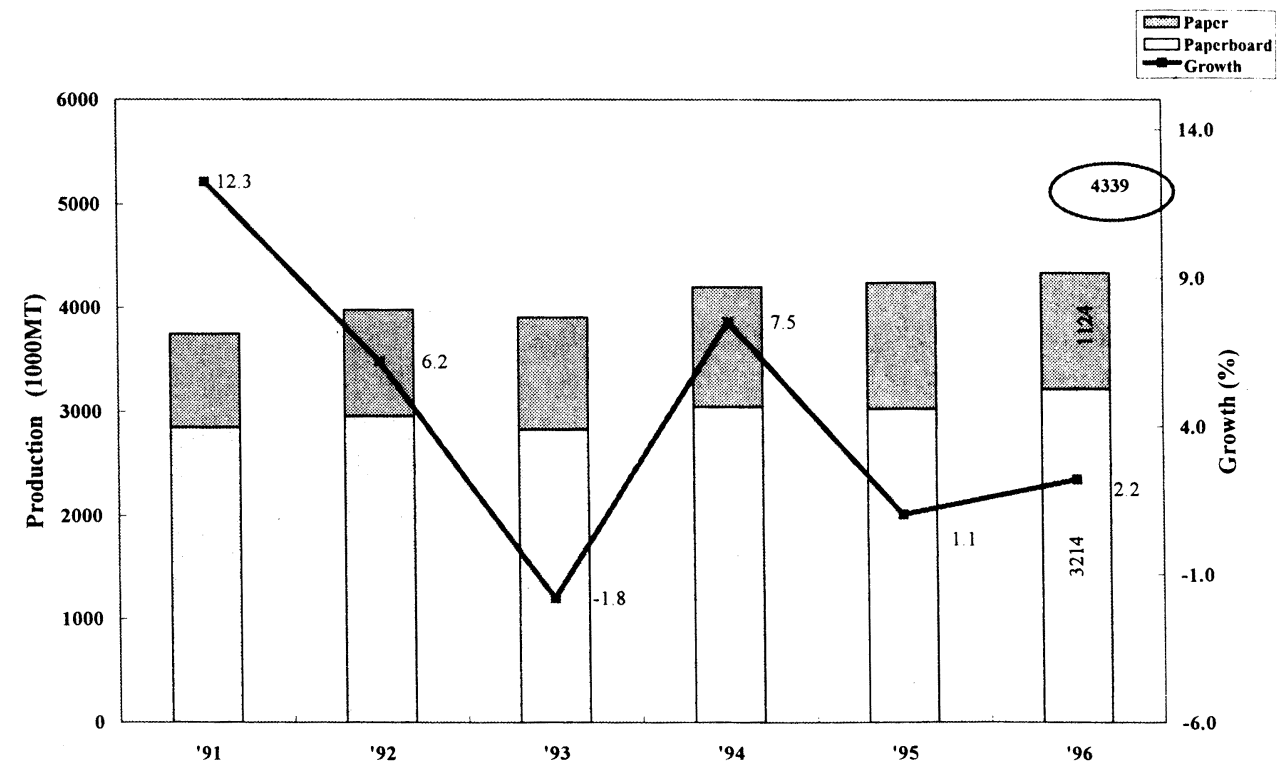

Fig.2 Production of Paper and Paperboard in Taiwan in Recent Years 
Table 1 Import and Export Dependencies and Growth of Various Grades of Papers in The Last Six-Year

\begin{tabular}{|c|c|c|c|c|c|c|c|c|c|}
\hline $90^{\prime}-96$ & $(\%)$ & Imp & Dep & \multirow[t]{2}{*}{ Paper } & \multirow[b]{2}{*}{ Grades } & \multicolumn{3}{|c|}{ Exp. Dep (\%) } & \multirow{2}{*}{$\frac{\text { '90-'96 }}{\text { Gwth of Prod. }}$} \\
\hline Gwth of Csp & 1990 & 1993 & 1996 & & & 1990 & 1993 & 1996 & \\
\hline 13.7 & 18.4 & 18.3 & 13.5 & $\mathrm{P} / \mathrm{W} \mathrm{P}$. & Coated & 36.2 & 25.3 & 25.5 & 7.9 \\
\hline 1.3 & 20.5 & 12.6 & 15.5 & & Uncoat. & 3.3 & 6.1 & 9.4 & 2.5 \\
\hline-0.2 & 28.9 & 60.3 & 66.0 & & Others & 11.1 & 1.8 & 0.0 & -9.4 \\
\hline 4.8 & 20.3 & 16.0 & 16.1 & & S. Total & 14.2 & 13.8 & 15.7 & 4.2 \\
\hline 1.2 & 43.6 & 57.6 & 68.8 & \multirow{5}{*}{\multicolumn{2}{|c|}{$\begin{array}{l}\text { Thin Papers } \\
\text { Newsprint } \\
\text { Household P. } \\
\text { Packaging P. } \\
\text { Miscellaneous P. }\end{array}$}} & 0.0 & 0.0 & 0.0 & -10.4 \\
\hline 4.1 & 71.9 & 81.6 & 87.8 & & & 7.5 & 0.0 & 0.0 & -6.7 \\
\hline 9.0 & 14.9 & 19.7 & 11.3 & & & 4.1 & 4.2 & 10.7 & 10.1 \\
\hline 3.0 & 34.8 & 47.4 & 47.1 & & & 0.7 & 8.6 & 1.5 & -0.7 \\
\hline 22.8 & 76.2 & 49.5 & 65.8 & & & 5.1 & 3.2 & 3.8 & 29.4 \\
\hline 6.9 & 38.9 & 39.9 & 42.6 & \multicolumn{2}{|c|}{ Paper Total } & 10.1 & 9.7 & 11.6 & 5.2 \\
\hline 4.5 & 39.9 & 40.9 & 42.9 & \multirow{2}{*}{\multicolumn{2}{|c|}{ Container Liner }} & 13.0 & 12.3 & 14.4 & 2.8 \\
\hline 4.6 & 7.7 & 9.5 & 8.9 & & & 9.7 & 11.7 & 17.1 & 6.2 \\
\hline 3.1 & 0.6 & 3.6 & 3.9 & \multirow[t]{2}{*}{ Board } & Medium & 18.4 & 12.2 & 19.2 & 3.0 \\
\hline 3.9 & 4.5 & 7.0 & 6.8 & & S. Total & 13.9 & 11.9 & 18.1 & 4.7 \\
\hline 1.9 & 4.4 & 1.1 & 1.6 & Duplex & Coated & 39.7 & 44.5 & 51.5 & 4.3 \\
\hline-24.3 & 7.4 & 33.4 & 33.3 & \multirow[t]{3}{*}{ Board } & Uncoat & 10.4 & 25.8 & 49.8 & -21.3 \\
\hline 5.4 & 1.5 & 0.6 & 1.5 & & Solid & 12.3 & 17.1 & 9.1 & 4.4 \\
\hline-1.5 & 4.9 & 3.9 & 3.1 & & S. Total & 33.0 & 41.7 & 48.7 & 1.7 \\
\hline 8.4 & - & 3.2 & 0.9 & \multirow{2}{*}{\multicolumn{2}{|c|}{$\begin{array}{l}\text { Chip Board } \\
\text { Miscellaneous B. }\end{array}$}} & 4.7 & 5.5 & 10.6 & 9.8 \\
\hline 30.9 & 69.8 & 93.6 & 92.7 & & & 15.3 & 6.1 & 1.7 & -0.5 \\
\hline 4.0 & 5.4 & 12.3 & 11.1 & \multicolumn{2}{|c|}{ Board Total } & 18.7 & 19.4 & 24.7 & 4.2 \\
\hline 5.1 & 17.4 & 23.0 & 23.6 & \multicolumn{2}{|c|}{ P \& B Total } & 16.5 & 16.7 & 21.3 & 4.5 \\
\hline
\end{tabular}

1996 年の紙板紙の年間消費量は, 456 万トンで, 過去 最高であった 1994 年の 473 万トン（図 3）には少し 及ばないが，人口一人当たりの平均消費量は $212 \mathrm{~kg}$ （図4）に達しており，世界の紙消費国のトップ10 位 以内にランクされる。

\section{2. パルプ原料供給}

(1) パルプ繊維に関しては，1996 年には 93 万トン の木材パルプ消費量である。その中で $76 \%$ に当たる 71 万トンが輸入であつた（図6)。この值は增加の傾 向にある。パルプの主要輸入相手国は北米であるが, この比率は最盛期の $60 \%$ 強から現在 $47 \%$ に落ちてい る。一方，チリおよびインドネシアからの輸入パルプ は增加しており，それぞれ16\%および6\%になってい
る（図 7, 8)。将来とも，この傾向は，地理面および コスト面から更に進むものと思われる。

（2）現在，台湾には 2 パルプ工場あって，ほとんど がLBKP 製造している。最近一部の生産ラインが NBKP に変更された。1996 年に，この 2 工場で 33 万トンの生産量で，その中 21 万トンは国内消費され ているが,これはパルプ需要の $24 \%$ にしかなない。 パルプ製造に必要な木材チップはほとんど全て輸入に 頼っている。過去には，主要なチップ供給地域は東南 アジア諸国であったが，最近では中国とロシアに変わ りつつある。

(3) 1996 年に, 再生パルプとして, 合計 425 万卜 ンの古紙が消費され，その中 166 万トンが輸入で $39 \%$ に当たる（図 9)。この比率はここ数年変化無く 


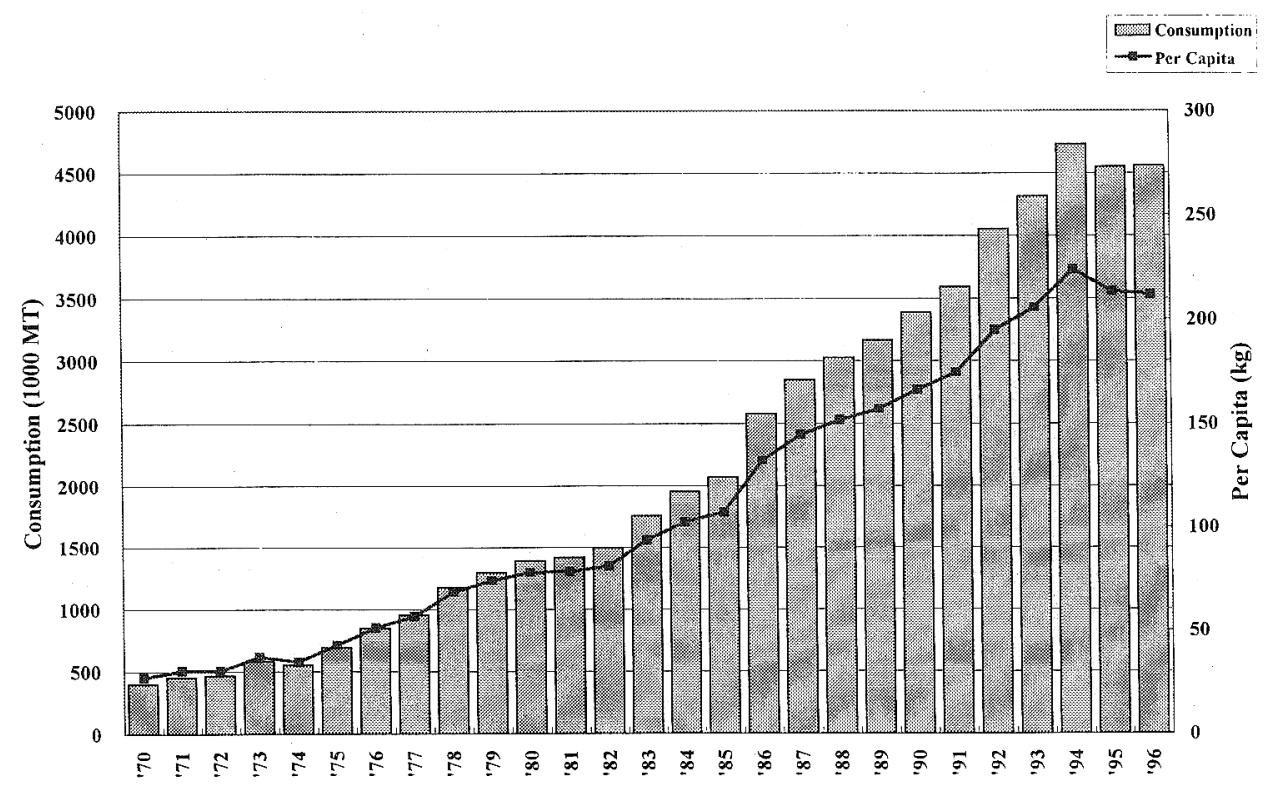

Fig. 3 Consumption of Paper and Paperboard in Taiwan over The Years

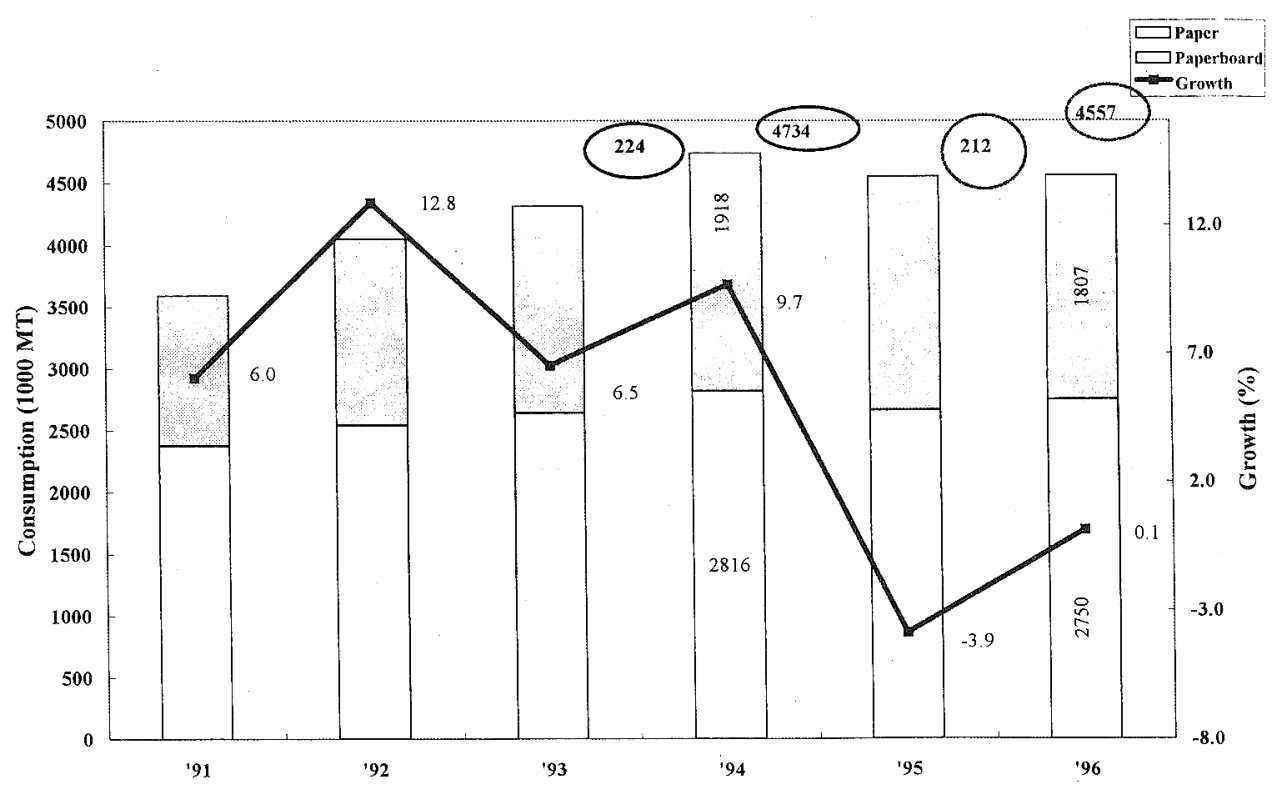

Fig. 4 Consumption of Paper and Paperboard in Taiwan in Recent Years 


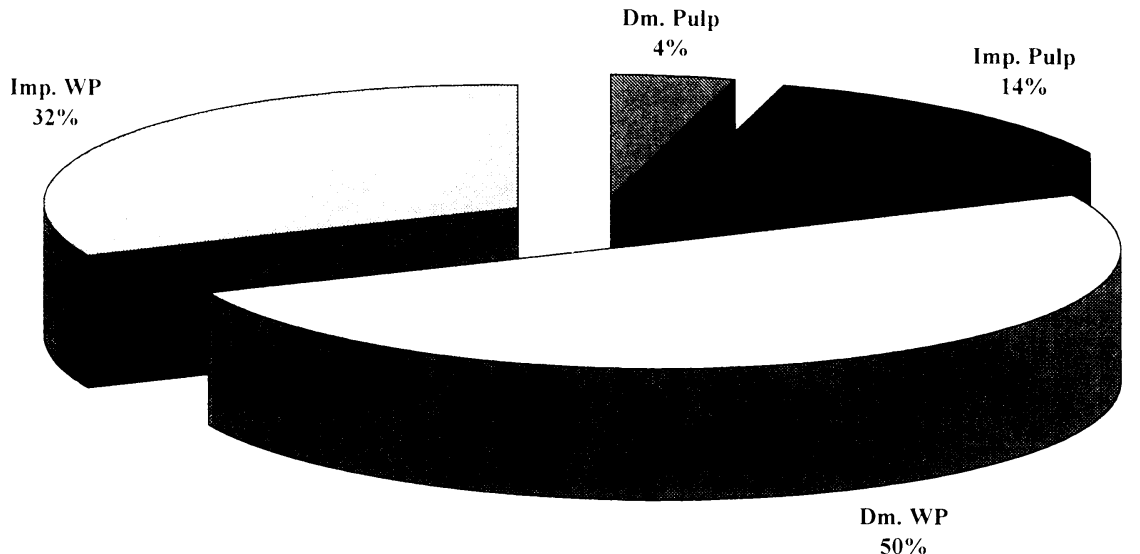

Fig.5 Raw Material Composition for Papermaking in '96

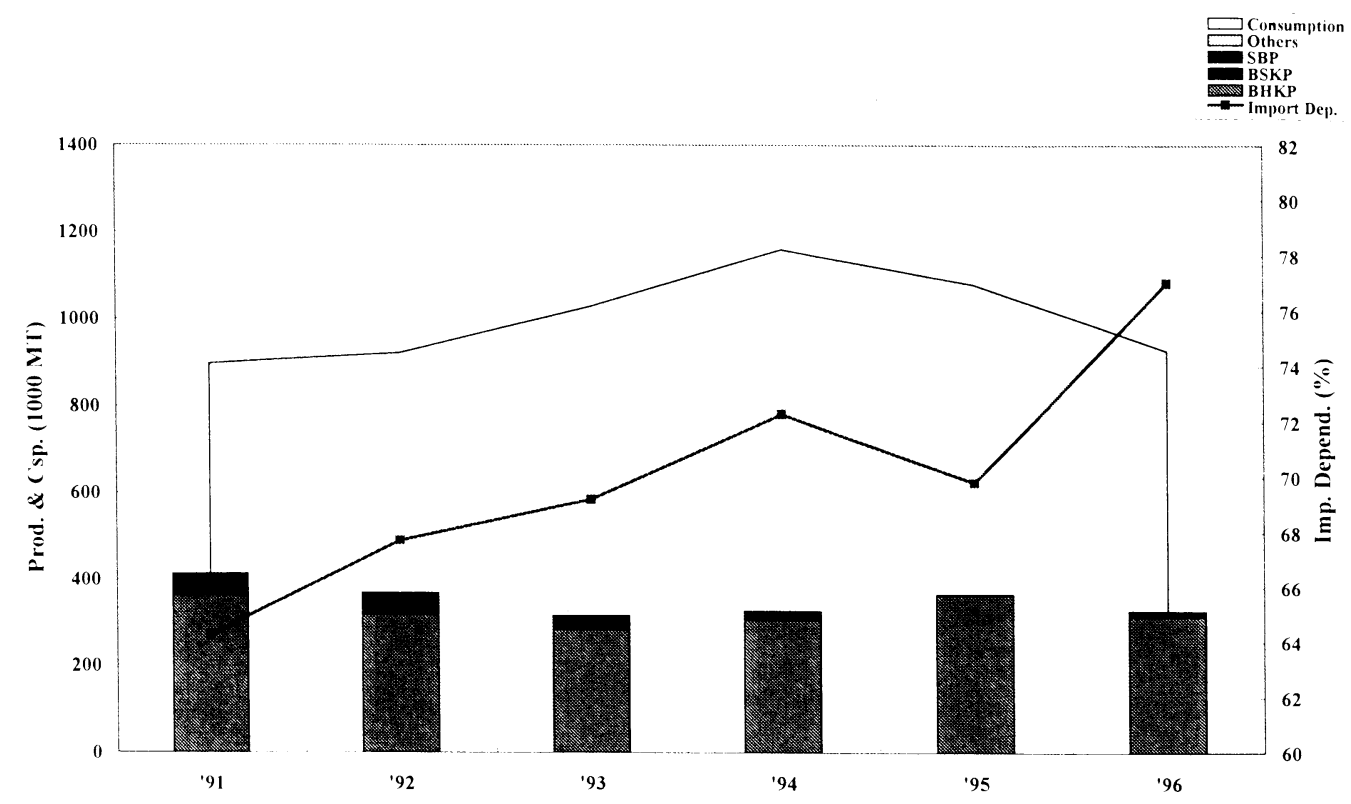

Fig.6 Production and Consumption of Pulp in Taiwan in Recent Years 


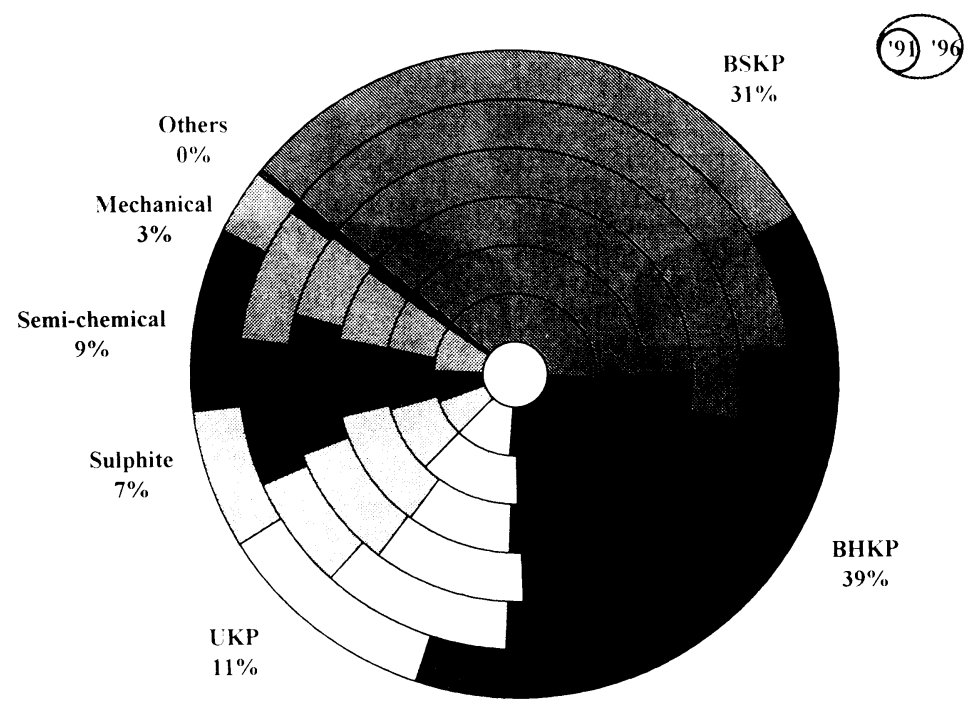

Fig.7 Composition of Imported Pulp in Recent Years

\section{Sources of Pulp Imports for}

Taiwan in ' 91

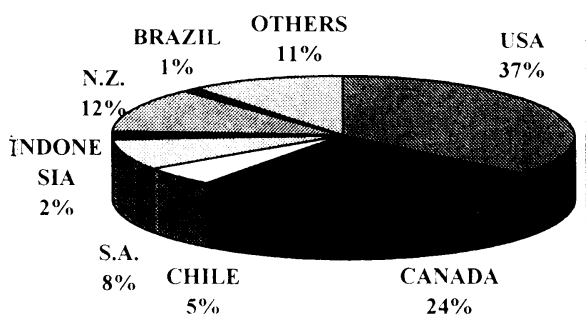

Sources of Pulp Imports for

Taiwan in ' 96

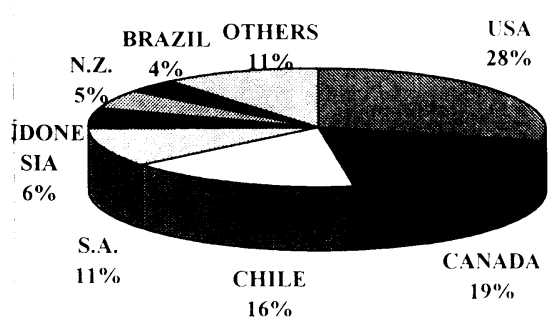

Fig 8 Sources of Pulp Imports

繶いている。北米は依然として最も重要な古紙輸入相 于㥵であって，全体の $69 \%$ となっているが，やや低 トの傾问を見せはじめている（図 10）。以前の香港に 取って変わって，ヨーロッパが汁紙輸入相手として急 浮にしてきて扔り，1996 年には，30\%に達した。段 ボールけ紙（OCC）が依然として主要な輸人古紙で あり，全体の $49 \%$ となっている。その次が新閂け紙 であるが、その比率はやや低卜して来ている（図 11）。

(4) ハルフフ原料は， $82 \%$ が古紙からで，残りの 18\%がバージンパルプである。国内汁紙からの再生原

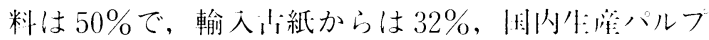
は $4 \%$ ，輸入パルプは $14 \%$ となっている。食パルフ原 料の輸入依存法は46\%である（図 5)。

(5)古紙利用比摔挹よびリサイクル比凃はここ数件 は间レベルに留まっている。1996 作には，そ机ぞ机， $79 \%$ 上 $57 \%$ であって，これらの比沙から，台湾は最 も高い活紙利用率扮よびリサイクル摔を小寸目々の一 つである（図 12）。このことは义，台游が、紙処理技 術に強みを持っていることを小唆している。 


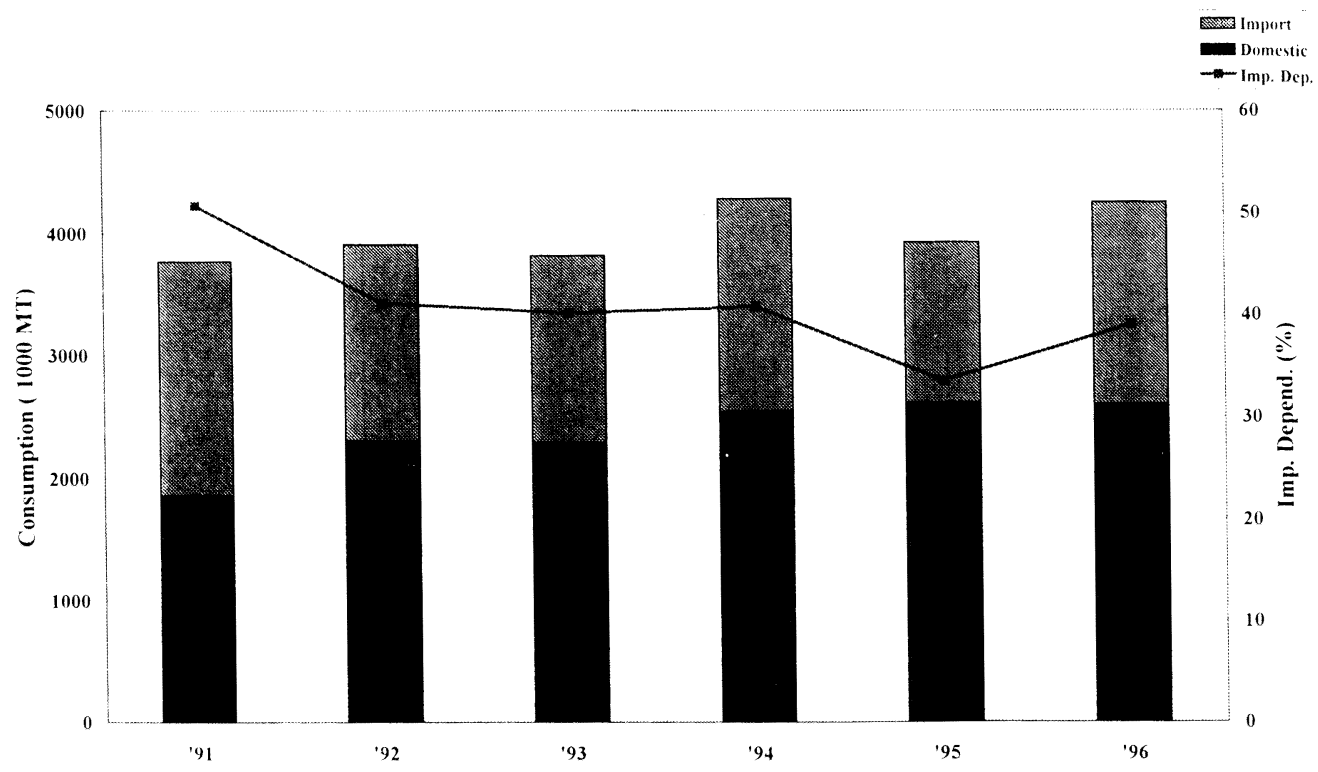

Fig.9 Wastepaper Consumption in Taiwan in Recent Years

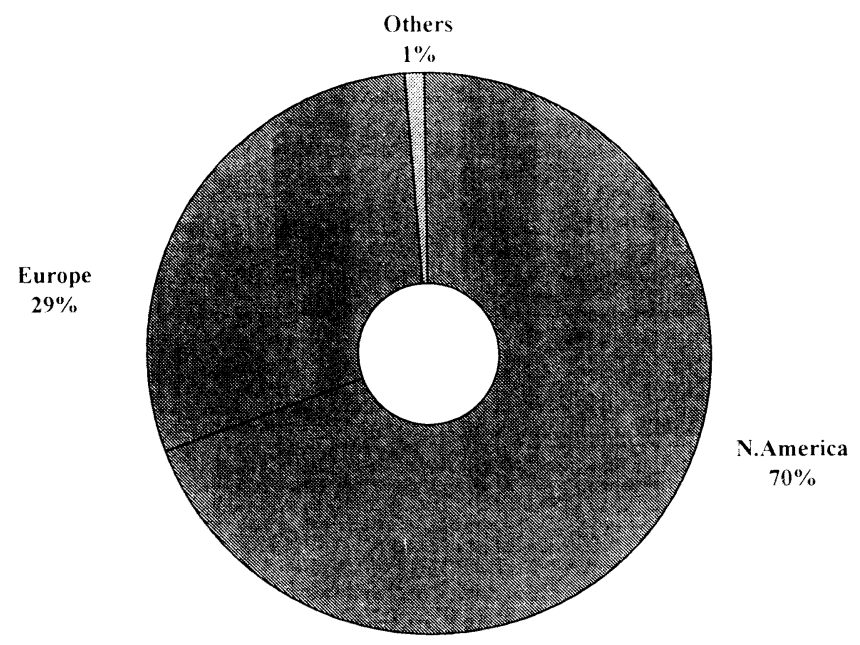

Fig.10 Sources of Wastepaper Imports for Taiwan in '96

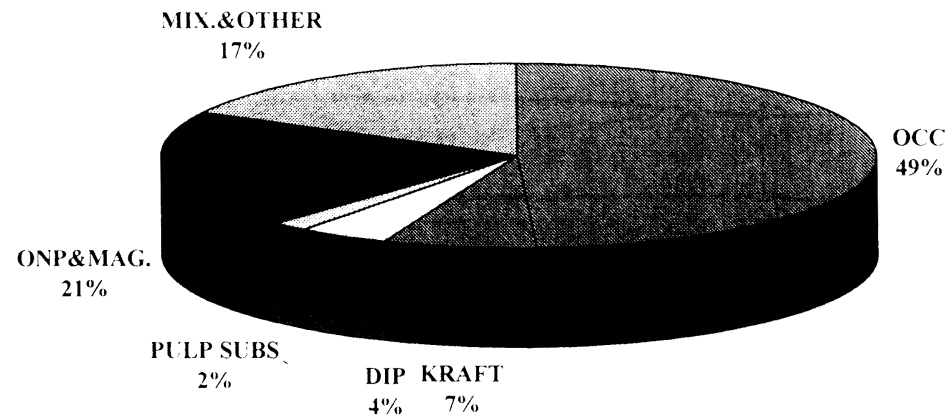

Fig.11 Composition of Imported Wastepaper for Taiwan in '96 


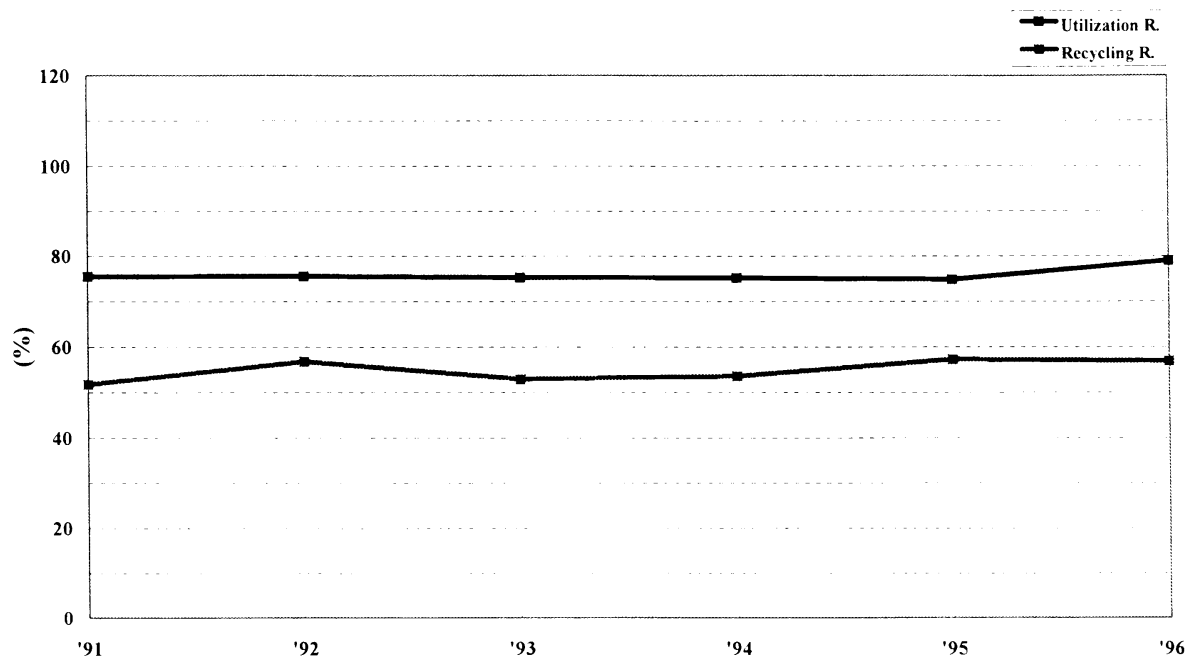

Fig.12 Wastepaper Utilization and Recycling Rate in Taiwan in Recent Years

\section{3. パルプ原料の動向とその対策}

(1) 原料と環境保護の制限から，台湾におけるパル プ製造の相対的優位性は失われている。将来，台湾の 製紙産業は, 継続的なパルプ原料供給，および将来と も永続的にこの産業を支えるなめに，海外の植林，千 ップ「埸，パルプ・製紙一貫工場のプロジェクトに関 寸るフィージビリティ評価を活発に行うであろう。

(2) パルプ「場は生産ラインをほとんどNBKPに 切り替えられると思われる。これは，LBKP の生产 でけ倒的に優位にあるインドネシアなどの国々と競争 を避けるためである。また，供給叮能な国内チップを 開発する以外に，ほとんどのチップは尚も輸入する必 装がある。

(3) 地理的要肉, 価格競争力および前提とされる品 質の諸条件から，インドネシアもしくはチリは，将来 台湾にとって 主要なパルプ輸入相手国となろう。

(4) 活紙は, 将来の台湾にとって最も重要なパルプ 原料であることには変わりない。け紙の出質および供
給量の確保が台湾の製紙産業に最も重要な影響を与え るであろう。

（5）哀年にわたって，台湾は古紙原料の处理方法や 利用について豊富な経験を培っており, この分野では, 諸外国と比較して先端的な技術を保持している。この ノウハウについて，喜んで近隣諸国の同業の友人に伭 えたいと思っている。

（6）米国における古紙利用の強化や，中国および東 南アジア諸国との競争から, 将来, 十紙は逼迫するで あろう。台湾は将来の安定供給のために, 古紙原料源 をより広く求めて行く事になろう。

（7）国内の古紙のリサイクルは既に上限に達してい るので, 将来は古紙の量的拡大より品質を向上させる ことに注力されるであろう。実際，製紙産業は政府と 共间して才町村から出る原料資源を有効に利用子るだ ろう。教青, ごみの分別化, 人々にとっての原料のリ サクルの重要性の認識を通して，低コストで宫品質な 古紙リサイクルの環境を創造して行くこょ，延いては これがより艮い競争を育むことを願っている。 